\title{
The Bright Future of Democracy is in Education
}

\author{
By Gregory T. Papanikos*
}

Does democracy have a bright future? This brief paper addresses this question and argues, that, thanks to Prometheus, political "animals" can build a bettermanaged corral for their common living which includes a better provision of education for all "animals." A historical analysis of the long past may be used to discern what lies ahead. Democracy requires education and virtue, or to put it in one word, it requires pedagogy. The higher the level of pedagogy, the closer a politeia would come to an ideal democracy. Sometimes democracy is confused with equality in everything. Political "animals" are not equal, and political systems which treat people with different abilities equally have no future. An ideal society should discriminate according to levels of education obtained and the acquisition of material wealth. If the politeia is ideal, then each citizen has the same opportunity to become more educated and wealthier. In this free competition of being educated and the acquisition of individually made material wealth, ideal societies can flourish as Hesiod postulated in the $8^{\text {th }}$ Century BCE and become stable despite Polybius' predictions in the $2^{\text {nd }}-1^{\text {st }}$ Century BCE of the inevitable historical cyclicality of political systems.

Keywords: education, pedagogy, democracy, oligarchy, monarchy, ochlocracy, tyranny, ideal politeia, Polybius

\section{Introduction}

This paper is based on chapter ten of my book Ten Lessons of Democracy published in Greek (Papanikos, 2020a). Based on this book, I have also examined elsewhere the definition of democracy and discussed the five criteria which can be used to evaluate political systems (Papanikos, 2022a). The purpose of this paper is to briefly express some thoughts on the future of democracy.

Democracy deals exclusively with political "animals." Inside the corral there are many and different "animals" - the more the better for the politeia. It is unbelievable the surge of political "animals" in the thousands of years for which we can speculate about their numbers. In 2020, about 8 billion such "animals" were living on planet earth. So far, no other flock of such "animals" have been founded elsewhere in the universe. According to United Nations (UN) statistics, in 100 years' time the planet will have $10^{10}$ political "animals." Somehow these animals must be organized to live together peacefully. They will need education with virtue.

\footnotetext{
"President, Athens Institute for Education and Research, Greece; Honorary Professor of Economics, University of Stirling, UK; and Professor, MLC Ljubljana, Slovenia.

${ }^{1}$ The latest UN projections can be downloaded here: https://population.un.org/wpp/Download/Stan dard/Population/.
} 
Religions teach virtue, but only to their own "animals."2 They pray for their own flock only. Even worse, their fanatic followers, usually without any education at all, wish the opposite for the other faiths' flock and in some not-so-few cases, they take matters (re: weapons) into their own hands and fight in the name of their own God to reduce the political "animals" of the other herds. This is not good for teaching morality and ethics. It seems that religions do not meet the herculean task of educating political "animals" to become better. There must be an alternative to war and ignorance. In Papanikos (2022a), I presented isopoliteia as one of the five criteria of democracy which is satisfied when all religions pray for all political "animals" of the world. This assumes that problems like military spending and fights over energy resources will be over ${ }^{3}$ and all disputes will be settled in a peaceful manner. ${ }^{4}$

The question asked in this paper is what will be the destiny of these political animals? Are they going to live in a better world than their ancestors? What is to be expected tomorrow? One thing is certain, the future is uncertain. All political "animals" will die one day but the issue is how to live between their birth and death. In his dialogue, the Apology of Socrates, Plato gives an excellent example of a political "animal," Socrates. He praised his city, Athens, because since his birth the politeia provided him with so many things, including of course pedagogy (or so he thought). In return, all the democratic city-state wanted from its citizens was to respect its laws because all citizens were equal before the politeia's lawsIsonomy they called it - And this is what Socrates did in 399 BCE at the age of 70 years old. He obeyed the laws of Athenian democracy and drank the conium because this was the decision of the 500 court-members of the Athenian democracy. Who said that a democracy is the perfect system? It is simply the best of all the implemented ones. Plato's Ideal Politeia is superior, but when Plato himself had the opportunity to implement it, he ended up in prison. For this reason, it was not an ideal after all if it cannot be implemented. Plato was sold as a slave. In his case, as in Aristotle's case, humanity did not repeat the same crime against philosophy.

Socrates was one of the best political "animals" that any ideal politeia would love to have. The bad decision of the Athenian court was due to lack of sufficient education, or to put it better, a lack of pedagogy, which is a combination of education (paideia) and virtue (agogi). Some educated citizens today are very sensitive to the issue of democracy. Through education their number can increase. ${ }^{5}$ In advanced countries, citizens are interested not only in promoting their own well-being and freedom, but the well-being and freedom of other people. As the number of political "animals" with pedagogy increases, the future of humanity

\footnotetext{
${ }^{2} \mathrm{I}$ use the word religious schematically to mean beliefs of something and no reference to a specific religion. Nevertheless, and despite the fact that the three big monotheist religions share the same God, they educate their followers that each one of them adopts the right dogma.

${ }^{3}$ Military spending, energy security and wars in general have been examined in Papanikos (2020h, 2015a, 2015b, 2000).

${ }^{4}$ This is not only a moral issue. It is quite possible that the material cost of wars outweighs the benefits of peace.

${ }^{5}$ For a relation between Education and Democracy, see Parziale and Vatrella (2019) and Coulter and Herman (2020).
} 
will be brighter, but even brighter will be the future of democracy. It is very difficult to tell the future but sometimes by looking at the past we can get a glimpse of what lies ahead for humanity and democracy. This is done in the next section of the paper.

\section{What Does the Past Tell us About the Future?}

The examination of the past is the subject matter of history. ${ }^{6}$ The past could be used to say something about the future. History's role is to guide us through the narrow alleys of the dark (unknown) past to shed light into the uncertain future of political "animals". In a summary form, I think the past can tell us the following things about the future. ${ }^{7}$

Firstly, political "animals" will continue to propagate themselves and therefore will increase in number which will put two types of interrelated pressures on democracy. The first is migration which is one coin with two sides: outmigration and immigration. Most countries in their histories experienced both outmigration and immigration, and both can occur concurrently. A good example is Greece, which in the last decade, had to cope with the immigration of a huge number of migrants (mainly refugees) and outmigration (brain drain). ${ }^{8}$ Migrated and nonmigrated political "animals" will need education. Currently in Greece, and in the European Union at large, one of their migration policy objectives is to educate the millions of migrants that come from all over the world in order to help their smooth integration into the society. ${ }^{9}$ Not only the children will need basic primary and secondary education, but the adults themselves require different kinds of education, primarily language skills.

Secondly, technology is growing at an exponential rate in the last thousand years and most probably will continue to increase in the future. ${ }^{10}$

Thirdly, as a result of the first two observations, one concludes that political "animals" have avoided the Malthusian trap because technology has increased. Despite the huge increase in the number of people, per capita income and per capita wealth have increased at a high rate if one compares centenary data. ${ }^{11}$ This was made possible because people now can produce many more goods and services than they were able to 100 years ago; this is called productivity of labour.

Fourthly, education is provided to more and more people, albeit not at the rate which will satisfy the precondition of an ideal democracy because the current

\footnotetext{
${ }^{6}$ The role of history as a tool of analysis is discussed in Papanikos (2020b, 2006, 2005). In general, in what it follows in this paper I cite my own work and the interested reader can find there all the references used. Most of these works use the historical experience of Greece as a case study but they can be easily generalized to other countries and regions.

${ }^{7}$ A similar approach of speculating about the future I followed in Papanikos (2000).

${ }^{8}$ I have examined some facets of Greek migration issues in Papanikos $(2003,1991)$.

${ }^{9}$ For more on immigrants' integration, see Lee and Weng (2019) and Karlis, Gravelle, Stratas, and Makrodimitris (2020).

${ }^{10}$ Some aspects of technology are examined in Papanikos (1994).

${ }^{11}$ Economic growth depends very much upon private and public investment; see Papanikos (1988).
} 
provision of education does not guarantee virtue yet. ${ }^{12}$ It is of interest the speed of spreading knowledge today due to advances in communication and transportation technology. The COVID-19 pandemic has forced the world to be educated remotely from one corner of the world to the other. ${ }^{13}$ Even though onsite education is much better because of the physical positive interaction effect, nevertheless for many citizens in the world this may not be possible and the alternative might have been no-education.

Fifthly, comparing with the past the five "iso"14 of democracy have been improving over the centuries even though not in a linear manner. In all five criteria, the political "animals" in total have achieved significant progress.

Sixthly, if these non-Euclidean trends continue, then Prometheus, sooner or later, will bring forth an ideal democracy — everything will be determined with algorithms. Even the isonomy will be determined in such a way that Hesiod would rest in peace because no judge will be bribed. ${ }^{15}$ This will be the result of not so much an increase of virtue, but definitely because of technology. A good example is the use of DNA in forensic cases.

Along with Plato, John Stuart Mill and John Dewey, I consider education as the most important variable which will determine the future course of democracy. This relationship is examined in the next section.

\section{The Future of Democracy Depends on the Pedagogy of Political "Animals"}

I consider education as the most important factor which will contribute to a better democracy, which makes Prometheus possible. However, as depicted in

\footnotetext{
${ }^{12}$ It is ATINER's mission to promote education and virtue by bringing academics together in Athens. The dissemination of knowledge takes the form of onsite gathering in Athens in ancienttype academic symposiums but books are also produced which include all the works presented.

${ }^{13}$ COVID-19 has affected many aspects of life including democracy itself as many citizens of the world have questioned the right of governments to enforce lockdowns and vaccinations. In a series of papers, I have examined the COVID-19 effects on various aspects of economic and social aspects of life; see Papanikos (2021a-2021c, 2020c-2020g). Also, many papers have been published in the various journals of ATINER on different issues of COVID-19: on Health (Menekli, Doğan, \& Yıldı, 2021; Papanikos, 2021b; Parodi, Maraglino, \& Caraglia, 2021; Shah, Ali, Naeemullah, \& Bilal, forthcoming), on Mass Media and Communication (Crescentini \& Padricelli, forthcoming; De Falco, Punziano, \& Trezza, 2021; Fitzpatrick, forthcoming; Mengu, Mengu, \& Gunay, 2021; Osisanwo, 2022), on Social Aspects (Bäckman, 2021; Jurić, forthcoming; Lust, forthcoming; Okaka \& Omondi, forthcoming, Papanikos, 2020g; Polo Martín, forthcoming), on Business and Economics (Adejare, Olaore, Udofia, \& Adenigba, forthcoming; Papanikos, 2021c; Reid, forthcoming; Struwig \& Watson, forthcoming; Uwah, Udoayang, \& Uklala, forthcoming), on Tourism (Gukiina \& Lamunu, 2021; Jones, forthcoming; Jones \& Comfort, 2020; Papanikos, 2020c), on Education (Güvercin, Kesici, \& Akbaşlı, forthcoming; Ismaili \& Ibrahimi, 2021; Papanikos, 2021a), and on Law (Iancu, 2021; Patraus \& Ofrim, 2021). A selection of these papers will be published in a book edition by Bigelow, Gkounta, and Papanikos (2022).

${ }^{14}$ In Papanikos (2022a), I have examined the five criteria of democracy which all start with the word "iso" which means equal: isegoria, isonomy, isoteleia, isocracy, and isopoliteia.

${ }^{15} \mathrm{In}$ a series of papers (Papanikos, 2022b, 2022c, 2022d, 2022e), I have examined Hesiod's contribution to economic analysis as well to institutions. Hesiod thought that learning was very important for an individual and society to flourish.
} 
Figure 1, this process would not be smooth (meaning linear) but there will be ups and downs, i.e., the trajectory will be non-Euclidean. Education is necessary but not sufficient. We now know from the white-collar crime idea that educated people can be criminals and can undermine the political process towards democracy. Thus, we need ethos as well. We need virtue; not only paideia, or as so eloquently was expressed in ancient Athenian democracy (see Plato's Protagoras), we need pedagogy. This is the reason that in the vertical axis of Figure 1, I add virtue to education. Without the two, democracy cannot progress. Once this has reached high levels as Plato's ideal society would have required, then the philosophers-kings will be chosen to rule the society. How? By democratic means of course. Not all people are able to achieve high levels of education, but all people can be self-ruled by the socially-accepted norms of morality, ethos and virtue.

When could all that be achieved? The most important thing is not the end, i.e., the ideal democracy, but the process which precedes its achievement. If we look at the past, then the future of democracy looks bright. There exists an unequivocal progress towards reaching the objective of an ideal democracy. The ideology of "perfectionism" or ideal should be changed with an ideology of "improvemenism." Making democracy better through education is an improvement and that is what history teaches us.

Would people be the same in an ideal democracy? Of course not. Most probably inequalities will be exacerbated which would be good from democracy's point of view and for the wellbeing of all its citizens. The practice, "one citizen = one vote" should be replaced by the individual right of more than one vote. People would be different in what they can achieve at the individual level. Some would be better in education than others. On the other hand, some would be so good with their way of material living that they could be able to produce income and accumulate wealth more than others. In an ideal democracy, equal treatment of non-equals is a great injustice, and since Hesiodic years a politeia cannot blossom, to use Hesiod's term, if its citizens are treated unfairly. There is no higher inequality than to exert the same political power to all citizens irrespectively of their education and their "handmade" material wealth. Many intellectuals have thought about these two issues and have proposed to normalize the process by giving more voting rights to "higher achievers."

One of the seven wise men of ancient Greece, named Solon, made the extent of political participation conditional on all of the citizens' accumulated wealth. In an ideal democracy, the individual accumulation of wealth is an additional indicator of people's ability to produce material goods and services; it is an indication of differentiation. Of course, in an ideal democracy making wealth immoral, unfair and unethical would not be possible. This idea can be traced back to John Locke (1632-1704) who argued that political authority is necessary to regulate and maintain the wealth made by individual work effort. Marx rightly argued that all wealth is produced by workers and therefore they have the right not only to appropriate it, but the right to political regulation of their affairs even if a revolution is needed. The problem is that there are huge differences between workers' productivities which Marx averaged them out, but in doing so he was 
able to iron out political abilities and differences as well. If workers are not the same where it counts, i.e., in the material base of society, shouldn't that then be reflected in the political representation as well? Yes, in socialism, but not in communism. However, then, the latter is a hysteresis and not a progress. This might explain that communism was never established, as Stalin himself admitted once. The labour theory of value is not Marx's idea. Originally it was developed by Hesiod in his Works and Days in the $8^{\text {th }}$ Century BCE (Papanikos, 2022b).

Figure 1. World Democracy Grows at a Non-Euclidean Rate

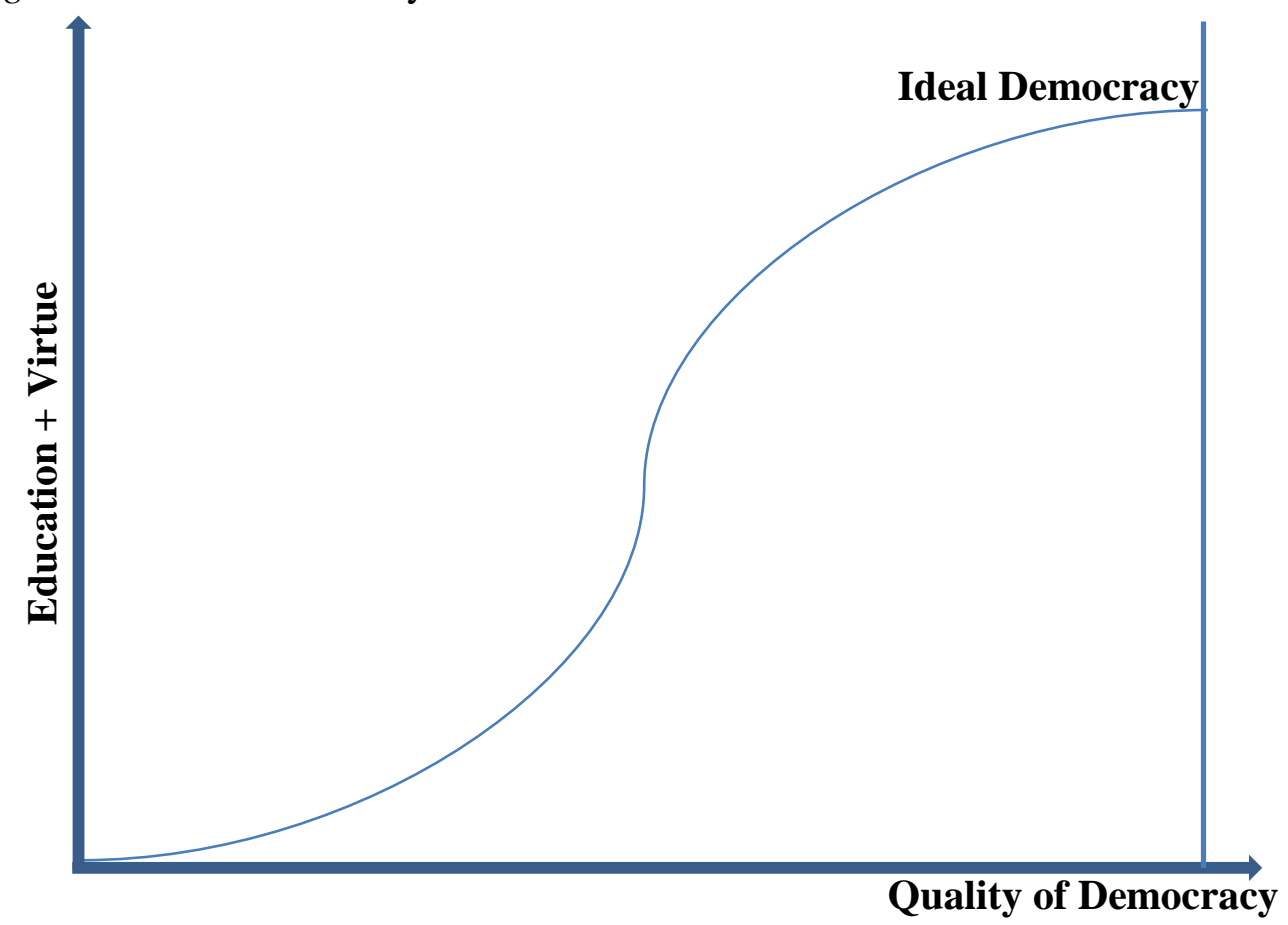

According to Solon and later Aristotle, those who have accumulated wealth have obligations and analogous political rights. In an ideal democracy this should be taken into consideration as well the accumulated education/knowledge of the political "animals." For example, for an additional one-million dollars which one earned by his own toil, one more vote will be allocated to him. Which one-million? Only the one he made himself and paid taxes on, because in the ideal democracy taxes will exist because they still are common goods such as free education. The isoteleia of an ideal democracy was examined in Papanikos (2022a). If wealth was inherited, then in cases that the heir reduced his wealth, he should not be allowed to have additional votes and will be decreased relative to the decrease in his wealth.

Accumulation of personal material wealth and accumulation of personal human capital (education) correlates with age. This solves another problem of representative democracy: time means aging. It takes time to acquire education and build up material wealth. Thus, an old citizen in the ideal democracy will have more votes if he was successful in accumulating knowledge and material wealth. In contrast with what Jan Jack Rousseau (1712-1778) suggested, the individual 
number of votes will not be independent of the level of education and the level of accumulated material wealth.

In conclusion of this section, in an ideal democracy citizens would be treated fairly. Those with more education and more material wealth would have more weight in decision making. If the number of political "animals" is large, as it is expected to be, then by the law of large numbers, the ideal democracy will always make the right decisions which will make all its citizens better off, spiritually (happiness) and materially.

One of the concerns of all those who think and write about political systems is the cyclicality of historical processes. The application of this idea to political systems is examined in the following section.

\section{Political Systems Come and Go}

What are the alternatives to organizing political "animals"? Table 1 presents six political systems which are determined by the existence of isonomy/ heteronomy on one hand, and how many are the rulers on the other. These political systems have been identified well in the ancient Greek thought and practice. Political systems can be characterized by isonomy which means that all are equal before the law; the opposite is heteronomy (notice that this is independent of how many rule the politeia). The number of rulers can be many, few or only one. Then, democracy is defined as the political system where the rule of law prevails and the many, not the few, rule the politeia which was Pericles' definition of democracy. Aristocracy is a political system in which, literally speaking, is the best (aristoi) rule - best in the sense that this politeia is ruled with isonomy. If few rule but there is no isonomy, then this system is called oligarchy. Finally, if one rules with isonomy, the political system may be called monarchy. In Plato's ideal politeia, this monarch would have been called philosopher-king. One man's rule with heteronomy characterizes tyranny.

Table 1. Political Systems in Plato's (Socrates') Thought

\begin{tabular}{|l|c|c|}
\hline $\begin{array}{c}\text { Rule of Law } \\
\text { Number of Rulers }\end{array}$ & Isonomy & Heteronomy \\
\hline Many & Democracy & Ochlocracy \\
\hline Few & Aristocracy & Oligarchy \\
\hline One & Monarchy & Tyranny \\
\hline
\end{tabular}


Figure 2. The History of Political Systems is Cyclical

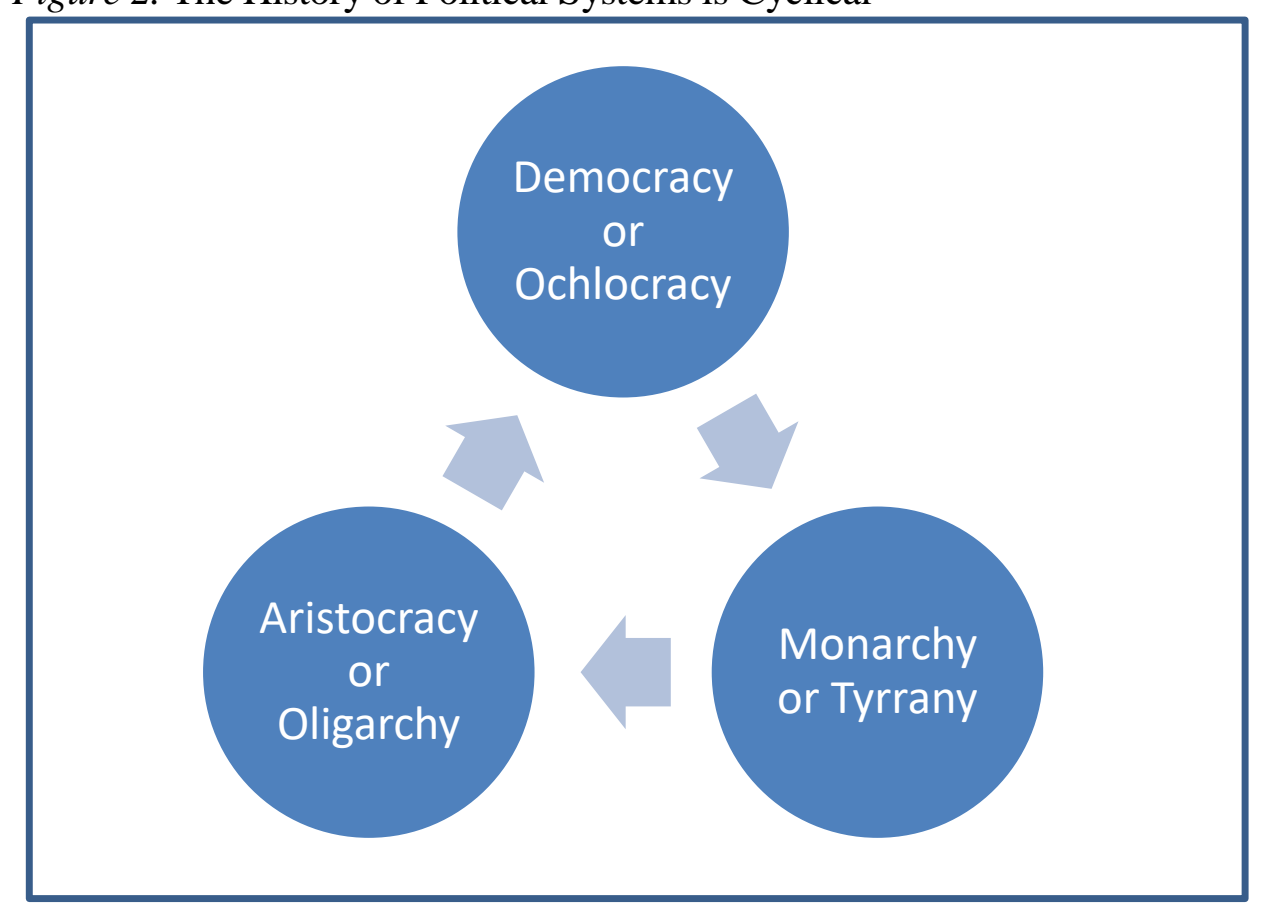

The question is whether there exists a historical tendency to converge a political system which is stable which hopefully would be democracy. No, said Polybius, a Greek historian of the $2^{\text {nd }}$ Century BCE. There is a cyclical turn of events as depicted in Figure 2. According to Polybius, monarchy tends to become a tyranny which is then overthrown by an aristocracy, which sooner or later becomes an oligarchy which suppresses its subjects, which then revolt and establish a democracy, which becomes by the passage of time an oligarchy.

\section{Conclusions}

This short paper examined the future of democracy, which, thanks to Prometheus, looks bright. Political "animals" are able to get more education which is a necessary condition to build a better politeia. It is not sufficient though; democracy requires its "animals" to have virtue. Pedagogy makes an ideal individual to be a citizen of an ideal democracy. In the meantime, and through education with virtue, political "animals" can become better. Improvement is the objective of a modern politeia. Perfection and other utopias can wait. 


\section{References}

Adejare, B. O., Olaore, G. O., Udofia, E. E., \& Adenigba O. A. (forthcoming). COVID-19 Pandemic and Business Survival as Mediation on the Performance of Firms in the FMCG-Sector. Athens Journal of Business \& Economics. Available at: https://www. athensjournals.gr/business/2021-4138-AJBE-Adejare-07.pdf.

Bäckman, G. (2021). The Outbreak of Coronavirus (COVID-19) plagues the world. Athens Journal of Social Sciences, 8(3), 181-190.

Bigelow, V., Gkounta, O., \& Papanikos, G. T. (2022). Themes on COVID-19. Athens: Athens Institute for Education and Research (ATINER).

Coulter, X., \& Herman, L. (2020). The Lure of Autocratic Education in a Somewhat Democratic Society. Athens Journal of Education, 7(4), 331-352.

Crescentini, N., \& Padricelli, G. M. (forthcoming). The Relevance of Scientific Dissemination During the Vaccine Campaign: The Italian Virologist Communication on Social Media. Athens Journal of Mass Media and Communications. Available at: https://www.athensjournals.gr/media/2021-4354-AJMMC-SOC-Crescentini-07.pdf.

De Falco, C. C., Punziano, G., \& Trezza, D. (2021). A Mixed Content Analysis Design in the Study of the Italian Perception of COVID-19 on Twitter. Athens Journal of Social Sciences, 8(3), 191-210.

Fitzpatrick, N. (forthcoming). No News is Not Good News: The Implications of News Fatigue and News Avoidance in a Pandemic World. Athens Journal of Mass Media and Communications. Available at: https://www.athensjournals.gr/media/2021-4336AJMMC-SOS-Fitzpatrick-05.pdf.

Gukiina, J., \& Lamunu, E. (2021). The Near Abasement of Uganda Hotels' Staff Altruistic Behaviour by COVID-19 Pandemic: A Relief Model. Athens Journal of Tourism, 8(4), 269-290.

Güvercin, D., Kesici, A. E., \& Akbaşl1, S. (forthcoming). Distance Education Experiences of Teacher-Parents During the COVID-19. Athens Journal of Education. Available at: https://www.athensjournals.gr/education/2021-4145-AJE-Kesici-05.pdf.

Iancu, L.-O. (2021). Insolvency of the Natural Person and COVID-19 in Romania. Athens Journal of Law, 7(4), 563-574.

Ismaili, J., \& Ibrahimi, E. H. O. (2021). The D-Learning Alternative During COVID-19 Crisis: A Preliminary Evaluation Based on Kirkpatrick's Model. Athens Journal of Technology and Engineering, 8(2), 181-198.

Jones, P. (forthcoming). A Review of the UK's Tourism Recovery Plans Post COVID-19. Athens Journal of Tourism. Available at: https://www.athensjournals.gr/tourism/20 21-4470-AJT-Jones-03.pdf.

Jones, P., \& Comfort, D. (2020). The COVID-19 Crisis, Tourism and Sustainable Development. Athens Journal of Tourism, 7(2), 75-86.

Jurić, T. (forthcoming). Google Trends as a Method to Predict New COVID-19 Cases and Socio-Psychological Consequences of the Pandemic. Athens Journal of Mediterranean Studies, 8(1), 67-92.

Karlis, G., Gravelle, F., Stratas, A., \& Makrodimitris, P. (2020). Inclusion and Integration: A Case Study of the Hellenic Community of Ottawa's Cultural Recreation Activities. Athens Journal of Social Sciences, 7(1), 39-48.

Lee, J. S., \& Weng, S. (2019). Building Bridges: Strategies to Overcome Challenges in Social Work with Immigrants and Refugees. Athens Journal of Social Sciences, 6(3), 213-228. 
Lust, J. (forthcoming). The Structural Conditions for the Expansion of COVID-19 in Peru. Athens Journal of Social Sciences. Available at: https://www.athensjournals.gr/social/ 2021-4173-AJSS-SOC-Lust-05.pdf.

Menekli, T., Doğan, R., \& Yıldız, E. (2021). Relationship Between Stress Perceived and Gastrointestinal Symptoms in Intensive Care Nurses During COVID-19 Pandemic: A Cross-Sectional Study. Athens Journal of Health and Medical Sciences, 8(4), 217230.

Mengu, S., Mengu, M., \& Gunay, K. (2021). Value-Based Communication During COVID-19 Pandemic: A Study on the Twitter Messages of Turkish Ministry of Health. Athens Journal of Mass Media and Communications, 7(1), 23-44.

Okaka, F. O., \& Omondi, P. (forthcoming). Knowledge, Attitude, and Practices (KAP) Towards COVID-19 Among Older People Living in Informal Settlements in Nairobi City, Kenya. Athens Journal of Social Sciences. Available at: https://www.athens journals.gr/social/2021-4430-AJSS-SOS-Okaka-05.pdf.

Osisanwo A (2022) "This Virus is a Common Threat to All Humans": Discourse Representation of COVID-19 in Selected Newspaper Editorials. Athens Journal of Mass Media and Communications, 8(1), 59-78.

Papanikos, G. T. (1988). Investment in Construction and Postwar Greek Economic Growth: A Correlation Analysis. Journal of the Hellenic Diaspora, XV(3-4), 75-86.

Papanikos, G. T. (1991). Greek Emigration to Canada: Economic or Political? In the Edition of the Proceedings of the First International Congress on the Hellenic Diaspora from Antiquity to Modern Times, Volume II, edited by J. M. Fossey, 321337. Montreal: McGill University Monographs.

Papanikos, G. T. (1994). Macroeconomic Impacts of Endogenous Technical Progress. Technological Forecasting and Social Change, 46(1), 17-28.

Papanikos, G. T. (2000). The Two Great Wars and the Two Great World Crises. Archives of Economic History, Special Issue, 99-106.

Papanikos, G. T. (2003). Issues on Greek Migration Trends and Policy Considerations. In Public Lecture of the Hellenic Observatory of the European Institute. London, UK: London School of Economics.

Papanikos, G. T. (2005). The Use of European History: Lessons for the 21st Century History. Mimeo.

Papanikos, G. T. (2006). The Use of History as a Tool of Policy-Making. Mimeo.

Papanikos, G. T. (2015a). Military Spending, International Trade and Economic Growth in the Mediterranean Basin. Athens Journal of Mediterranean Studies, 1(2), 187-194.

Papanikos, G. T. (2015b). Energy Security, the European Energy Union and the Mediterranean Countries. In the Roundtable Discussion on Energy Security and Policy in the South European Peninsula and the Mediterranean Basin. Athens: Athens: Athens Institute for Education and Research (ATINER).

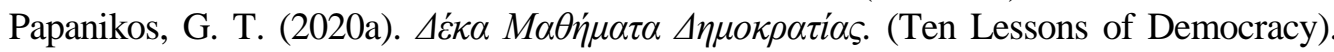
Athens: Athens: Athens Institute for Education and Research (ATINER).

Papanikos, G. T. (2020b). What is History? An Assessment of Carr's Monograph. Athens: Athens: Athens Institute for Education and Research (ATINER).

Papanikos, G. T. (2020c). The Impact of the COVID-19 Pandemic on Greek Tourism. Athens Journal of Tourism, 7(2), 87-100.

Papanikos, G. T. (2020d). Do National Health Expenditures Matter for the COVID-19? Evidence from the European Union. Mimeo.

Papanikos, G. T. (2020e). Influenza, Traffic Accidents and Coronavirus in Greece. Mimeo.

Papanikos, G. T. (2020f). The Economic Impact of the 2020 Pandemic in the European Union. Working Paper. Available at: https://www.atiner.gr/gtp/Papanikos(2020)GDP.pdf 
Papanikos, G. T. (2020g). The Demographics of COVID-19 in the European Union. Athens Journal of Social Sciences, 7(4), 279-290.

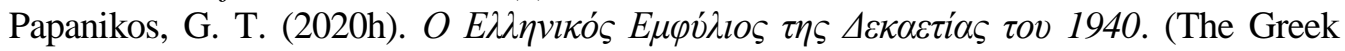
Civil War in the 1940s). Athens: Athens: Athens Institute for Education and Research (ATINER).

Papanikos, G. T. (2021a). Thucydides and the Synchronous Pandemic. Athens Journal of History, 7(1), 71-94.

Papanikos, G. T. (2021b). Deaths due to COVID-19, Lockdowns, Vaccinations and Weather Temperatures: The Case of Greece. Athens Journal of Health and Medical Sciences, 8(3), 201-216.

Papanikos, G. T. (2021c). The European Union's Recovery Plan: A Critical Evaluation. Athens Journal of Mediterranean Studies, 7(2), 85-102.

Papanikos, G. T. (2022a). The Five Ancient Criteria of Democracy: The Apotheosis of Equality. Athens Journal of Humanities \& Arts (forthcoming).

Papanikos, G. T. (2022b) Hesiod's Days and Works. Athens Journal of Business and Economics (forthcoming).

Papanikos, G. T. (2022c). Hesiod's Place in the Economics Literature. Athens Journal of Business and Economics (forthcoming).

Papanikos, G. T. (2022d). Hesiod's Theory of Economic History. Athens Journal of History (forthcoming).

Papanikos, G. T. (2022e). Hesiod on Scarcity. Athens Journal of Business and Economics (forthcoming).

Parodi P, Maraglino F, \& Caraglia A (2021). The Impact of COVID-19 Epidemic on Immunization Activities in Italy. Athens Journal of Health and Medical Sciences, 8(1): 53-66.

Parziale, F., \& Vatrella, S. (2019). Education and Universalism in Europe: When Education Supports Democracy. Athens Journal of Social Sciences, 6(2), 113-138. https:// www.athensjournals.gr/social/2019-6-2-3-Parziale.pdf.

Patraus ME, \& Ofrim IM (2021). Contractual Unpredictabiliy in the Context of COVID19 Pandemic. Athens Journal of Law 7(4): 485-506.

Polo Martín, B. (forthcoming). COVID-19: Cartography as a Witness of Change of Spanish Urban Models Along History due to Sanitary Crisis. Athens Journal of Mediterranean Studies, 8(1), 29-48.

Reid, J. L. (forthcoming). The Economic Effect of the COVID-19 Lockdown in the United States: Was the Cure Worse than the Disease? Athens Journal of Health and Medical Sciences. Available at: https://www.athensjournals.gr/health/2021-4261AJHMS-POL-Reid-05.pdf.

Shah, F. A., Ali, M. A., Naeemullah, \& Bilal, M. (forthcoming). A Study of Paediatric Supracondylar Fractures of the Humerus Presented During the COVID-19 Pandemic. Athens Journal of Health and Medical Sciences. Available at: https://www.athens journals.gr/health/2020-3855-AJHMS-Shah-09.pdf.

Struwig, M., \& Watson, S. (forthcoming). Working Capital Management and Systems Disruption During the COVID-19 Pandemic: Evidence from South Africa. Athens Journal of Business \& Economics. Available at: https://www.athensjournals.gr/busi ness/2021-4266-AJBE-MGT-Struwig-05.pdf.

Uwah, U. E., Udoayang, J. O., \& Uklala, P. A. (forthcoming). Post COVID-19 and the Acceptance of Financial Inclusion as a New Normal in Financial Transactions: Implications for Nigerian Accountants and Other Financial Service Providers. Athens Journal of Business \& Economics. Available at: https://www.athensjournals.gr/busi ness/2020-3821-AJBE-ACC-Uwah-05.pdf. 
